ISSN 0258-7122

Bangladesh J. Agril. Res. 35(3) : 497-505, September 2010

\title{
EFFECTS OF DIFFERENT AGED POULTRY LITTER ON THE YIELD AND NUTRIENT BALANCE IN BORO RICE CULTIVATION
}

\author{
A.T.M. S. HOSSAIN ${ }^{1}$, F. RAHMAN ${ }^{2}$, P. K. SAHA ${ }^{3}$ \\ AND A.R.M. SOLAIMAN ${ }^{4}$
}

\begin{abstract}
A two years' field trial was conducted to evaluate the effect of poultry litter (PL) incorporation of different ages on the yield, nutrient uptake and nutrient balance in Boro rice at BRRI experimental farm, Gazipur (AEZ-28 and land type-High Land) during 2004-05 and 2005-06 Boro seasons. Eight treatment combinations with different aged PL and chemical fertilizers along with a control treatment (no fertilizer) were tested. The treatment combinations were 0, 30, 60, 90, and 120 days' aged poultry litter, farmers' 135 days aged poultry litter and 50\% of soil test based (STB) chemical fertilizers. All PL treatments received poultry litter 3 t/ha and $50 \%$ of STB chemical fertilizers. In both years, 30 days old PL produced significantly higher rice yield with higher nutrient uptake.
\end{abstract}

Keywords: Poultry litter, aging, grain yield, nutrient balance.

\section{Introduction}

Poultry litter (PL) has been proved to be a good source to supplement chemical fertilizers in the rice-rice cropping pattern (BRRI, 1998-1999). This material contains not only $\mathrm{N}$, but also other elements like $\mathrm{P}, \mathrm{K}, \mathrm{S}, \mathrm{Ca}, \mathrm{Mg}$, and micronutrients (Egrinya et al., 2001). Approximately $75 \%$ of the total $\mathrm{N}$ and majority (90-100\%) of the $\mathrm{P}$ and $\mathrm{K}$ in poultry litter are available for plant during the year of application (Hammond et al., 1997). At present, about 2 million tons of poultry manure is produced in Bangladesh which can supply about $3 \mathrm{~kg} \mathrm{P}$ /ha/yr (Rijpma and Jahiruddin, 2004) and application of 2 tons of poultry manure/ha may replace the full dose of $\mathrm{P}$ and $\mathrm{S}$ and $60 \% \mathrm{~N}$ and $\mathrm{K}$ fertilizer requirement for target yield of 5-6 t/ha rice (Miah et al., 2006). Poultry litter contains significant amount of micronutrients that may be beneficial to crops. So, poultry litter, which is bulging in city vicinity, would be useful in crop field, otherwise it would be difficult to dispose them and create environmental pollution. Another important factor is soil organic matter that has been depleted by $9-45 \%$ during the period from $1969-70$ to $1989-90$ and more than $60 \%$ of arable lands of this country have low organic matter content, usually below $1 \%$ (Karim et al., 1994). In this situation, poultry litter can play a vital role for maintaining soil fertility. Because the application of manure increased total $\mathrm{C}$ and

\footnotetext{
${ }^{1,2 \& 3}$ Soil Science Division, Bangladesh Rice Research Institute (BRRI), Gazipur, ${ }^{4}$ Professor, Department of Soil Science, Banghabandhu Sheikh Mujibur Rahman Agricultural University (BSMRAU), Gazipur, Bangladesh.
} 
total $\mathrm{N}$ in soil, while the application of nitrogen fertilizer (inorganic) increased neither carbon nor nitrogen in soil (Dick and Christ, 1995).

Long-term manure applications increased soil CEC by increasing total organic carbon. Due to lower C: $N$ ratio, from poultry litter (C: $N=5.3)$ and composted poultry litter (C: $\mathrm{N}=8.2$ ) (Chanyasak et al., 1983), nutrients are mineralized easily and become available to plants. Initially all the organic materials have higher $\mathrm{C}$ : $\mathrm{N}$ ratio compared to the later stage. So, poultry litter should be stored for short periods in amounts that supply the needs of the current growing season. Storing litter for longer period may reduce the nutrient value and increase environmental risk and liability, especially if the material is not covered. Major $\mathrm{N}$ losses occur when manure is dried by sun and air movements or leaching by rain, as in case in open lot system (Hammond et al., 1997). In contrast, manure losses comparatively little $\mathrm{N}$, in a completely covered facility. In open systems, $40-50 \% \mathrm{P}$ and $\mathrm{K}$ are lost by runoff and leaching (Hammond et al., 1997). So, storing system and storing time of poultry manure are important factors in terms of nutrition value for field application. Study on the age or storing time of poultry litter to apply in rice field is scanty. Considering these, a study was undertaken to determine the optimum duration for decomposition of poultry litter and its effect on yield, nutrient uptake and nutrient status of wetland rice soil.

\section{Materials and Method}

Field experiments were conducted at BRRI experimental farm, Gazipur during Boro 2004-05 and 2005-06. The soil of the experimental field was clay loam in texture having $\mathrm{pH} 6.55$, organic matter $1.62 \%$, total $\mathrm{N} 0.11 \%$, available $\mathrm{P} 4.4$ $\mu \mathrm{g} / \mathrm{g}$, exchangeable K $0.17 \mathrm{meq} / \mathrm{l} 00 \mathrm{~g}$ soil, available $\mathrm{S} 4.3 \mu \mathrm{g} / \mathrm{g}$ and available $\mathrm{Zn}$ $1.6 \mu \mathrm{g} / \mathrm{g}$.

\section{Collection and decomposition of poultry litter}

Poultry litter was collected at different days and allowed for natural decomposition before setting the experiment in the field. The litter was collected from a selected layer type commercial poultry farm in Gazipur. Fresh poultry litter (one day after dropping) was collected from five selected days in every month. The collected poultry litter was hipped in pits in every month for natural decomposition under shaded condition.

The experiment comprised eight treatments including control. The following treatments were tested: $T_{1}=$ No PL and no chemical fertilizer (CF), $T_{2}=$ fresh PL, $\mathrm{T}_{3}=30$ days old PL, $\mathrm{T}_{4}=60$ days old PL, $\mathrm{T}_{5}=90$ days old PL and $\mathrm{T}_{6}=120$ days old PL, $\mathrm{T}_{7}=$ Farmer's preserved PL, and $\mathrm{T}_{8}=50 \%$ STB chemical fertilizer dose. Poultry litter was applied @ 3 t/ha (OD basis) only in Boro season before 
2-3 days of transplanting. All treatments received a blanket dose of 50\% STB chemical fertilizer (N-P-K-S-Zn@63-17-25-12.5-0 kg/ha) except $\mathrm{T}_{1}$ and $\mathrm{T}_{8}$.

The sources of $\mathrm{N}, \mathrm{P}, \mathrm{K}$, and $\mathrm{S}$ were urea, triple super phosphate, muriate of potash, and gypsum, respectively. One-third of $\mathrm{N}$ and the whole amount of $\mathrm{P}, \mathrm{K}$, and $\mathrm{S}$ were applied at final land preparation. The remaining two-thirds $\mathrm{N}$ were applied in two equal installments at 25-30 days after transplanting (DAT) and at 7 days before panicle initiation stage. In Boro season, 40 days old two rice seedlings of BRRI dhan 29 were transplanted at $20 \mathrm{~cm} \times 20 \mathrm{~cm}$ spacing. The design of the experiment was RCBD with 3 replications.

Appropriate cultural and management practices including plant protection measures were followed during each growing season. The individual plot size was $4 \mathrm{~m} \times 4 \mathrm{~m}$. The crops were harvested at maturity from $2.5 \mathrm{~m} \times 2 \mathrm{~m}$ area. Grain yields were recorded at $14 \%$ moisture and straw yields at sun dry basis.

\section{Chemical analysis of poultry litters, rice grain, and straw}

Different aged decomposed poultry litter samples; rice grain and straw samples of Boro rice were analyzed for determination of $\mathrm{N}, \mathrm{P}, \mathrm{K}$, and $\mathrm{S}$ in the Soil Science Laboratory, BRRI, Gazipur. For the P, K, and S analysis, samples were digested with di-acid mixture of nitric and perchlororic acid at the ratio 5:2 following the method described by Yoshida et al. (1976). The $\mathrm{N}$ analysis was made by Micro-Kjeldahl distillation method (Yoshida et al., 1976).

\section{Results and Discussion}

\section{Nutrient content in poultry litter}

Nutrient content in poultry litter (PL) varied significantly with decomposition period (Table 1). Significant amounts of macro and micro nutrients were present in different aged poultry litter. Poultry litter contained not only $\mathrm{N}$, but also other nutrients like $\mathrm{P}, \mathrm{K}, \mathrm{S}, \mathrm{Ca}, \mathrm{Mg}$ and micronutrients in a significant amount as reported by Saha et al. (2004). Fresh PL (0 day age) was rich in all types of plant nutrients. Nutrient content decreased as decomposition period advanced. Significant amount of nutrient was lost due to increase of decomposition period at different ways. This result was supported by Eghball et al. (1997) who found 20 to $40 \%$ loss of total $\mathrm{N}$ and 46 to $62 \%$ loss of total C during composting of cattle feedlot manure, as well as significant losses of $\mathrm{K}(>6.5 \%$ of total $\mathrm{K})$ in runoff from composting during rainfall. Farmers preserved PL (135 days aged) contained minimum amount of nutrients. Among the different aged PL, significant amount of nutrient was present in 30 days aged PL compared to other aged PL. 
Table 1. Nutrient content in different aged poultry litter.

\begin{tabular}{l|c|c|c|c|c|c|c|c|c}
\hline $\begin{array}{c}\text { Decomposition } \\
\text { period (day) }\end{array}$ & $\begin{array}{c}\text { Moisture } \\
(\%)\end{array}$ & N\% & P\% & K\% & S\% & $\begin{array}{c}\text { Zn } \\
(\mu \mathrm{g} / g)\end{array}$ & $\begin{array}{c}\text { Ca } \\
(\%)\end{array}$ & $\begin{array}{c}\text { Mg } \\
(\%)\end{array}$ & $\begin{array}{c}\text { Mn } \\
(\mu g / g)\end{array}$ \\
\hline 0 & $71 \mathrm{a}$ & $2.25 \mathrm{a}$ & $2.45 \mathrm{a}$ & $2.23 \mathrm{a}$ & $1.20 \mathrm{a}$ & $421 \mathrm{a}$ & $5.55 \mathrm{a}$ & $0.45 \mathrm{a}$ & $345 \mathrm{a}$ \\
30 & $56 \mathrm{~b}$ & $2.05 \mathrm{a}$ & $2.43 \mathrm{a}$ & $2.00 \mathrm{~b}$ & $1.11 \mathrm{a}$ & $384 \mathrm{~b}$ & $4.95 \mathrm{~b}$ & $0.40 \mathrm{a}$ & $318 \mathrm{~b}$ \\
60 & $46 \mathrm{c}$ & $1.50 \mathrm{~b}$ & $1.94 \mathrm{~b}$ & $1.54 \mathrm{c}$ & $0.95 \mathrm{~b}$ & $347 \mathrm{c}$ & $4.50 \mathrm{c}$ & $0.39 \mathrm{a}$ & $315 \mathrm{~b}$ \\
90 & 33d & $1.22 \mathrm{c}$ & $1.75 \mathrm{c}$ & $1.15 \mathrm{~d}$ & $0.73 \mathrm{c}$ & $313 \mathrm{~d}$ & $4.25 \mathrm{~cd}$ & $0.38 \mathrm{a}$ & $306 \mathrm{~b}$ \\
120 & $24 \mathrm{e}$ & $0.83 \mathrm{~d}$ & $1.62 \mathrm{c}$ & $0.80 \mathrm{e}$ & $0.53 \mathrm{~d}$ & $284 \mathrm{e}$ & $4.20 \mathrm{~d}$ & $0.37 \mathrm{a}$ & $294 \mathrm{bc}$ \\
$135(\mathrm{FP})$ & $19 \mathrm{e}$ & $0.55 \mathrm{e}$ & $0.94 \mathrm{~d}$ & $0.75 \mathrm{e}$ & $0.45 \mathrm{~d}$ & $231 \mathrm{f}$ & $4.10 \mathrm{~d}$ & $0.35 \mathrm{a}$ & $271 \mathrm{c}$ \\
\hline
\end{tabular}

Means followed by same letter in a column do not differ significantly by $5 \%$ level of DMRT

\section{Grain and straw yield of Boro rice}

In Boro season, application of PL significantly increased the grain and straw yields in both years (Table 2). The highest grain yield (6.32 t/ha in 2005 and 6.45 t/ha in 2006) was produced by $\mathrm{T}_{3}$ (30 days old PL) followed by $\mathrm{T}_{4}$. After 30 days, a decreasing trend of yield was observed with increasing the preservation time of poultry litter due to the gradual loss of nutrients for long-time preservation. In case of $\mathrm{T}_{2}$ treatment where fresh PL was applied, the yield (5.24 t/ha and 5.54 t/ha in Boro 2005 and 2006, respectively) was comparatively low compared to $T_{3}$ treatment due to late availability of nutrients for plant growth. Application of PL as preserved by farmers produced lower yield than the others, but still this yield was significantly higher than that of control plot (no PL). The yield obtained with 50\% STB (4.04 t/ha) was lower compared to these PL treated plots showing a beneficial effect of PL on rice production. This result was supported by Miah et al. (2006), reported that application of 2 tons poultry litter per hectare in low organic matter containing soil in combination with moderate dose of $\mathrm{N}$ (30-60 $\mathrm{kg} / \mathrm{ha}$ ) gave better yield (5.5 to $6.5 \mathrm{t} / \mathrm{ha}$ ) as compared to higher $\mathrm{N}$ levels (80-120 $\mathrm{kg} / \mathrm{ha}$ ).

Table 2. Effect of different aged poultry litter on the grain and straw yields of Boro rice.

\begin{tabular}{l|llll|lll}
\hline \multirow{2}{*}{ Treatment } & \multicolumn{3}{c|}{ Grain yield (t/ha) } & \multicolumn{3}{c}{ Straw yield (t/ha) } \\
\cline { 2 - 7 } & \multicolumn{2}{|c}{2005} & 2006 & Mean & 2005 & 2006 & Mean \\
\hline $\mathrm{T}_{1}$ (no PL) & $2.59 \mathrm{e}$ & $2.69 \mathrm{f}$ & 2.64 & $2.93 \mathrm{e}$ & $3.03 \mathrm{f}$ & 2.98 \\
$\mathrm{~T}_{2}$ (freshPL) & $5.24 \mathrm{bc}$ & $5.54 \mathrm{bc}$ & 5.39 & $5.51 \mathrm{~b}$ & $7.17 \mathrm{a}$ & 6.34 \\
$\mathrm{~T}_{3}$ (30 days old PL) & $6.32 \mathrm{a}$ & $6.45 \mathrm{a}$ & 6.39 & $6.26 \mathrm{a}$ & $6.76 \mathrm{a}$ & 6.51 \\
$\mathrm{~T}_{4}$ (60 days old PL) & $5.56 \mathrm{~b}$ & $5.65 \mathrm{~b}$ & 5.61 & $5.8 \mathrm{lb}$ & $6.23 \mathrm{~b}$ & 6.02 \\
$\mathrm{~T}_{5}$ (90 days old PL) & $5.14 \mathrm{bc}$ & $5.45 \mathrm{bc}$ & 5.30 & $5.58 \mathrm{~b}$ & $5.92 \mathrm{bc}$ & 5.75 \\
$\mathrm{~T}_{6}$ (l20 days old PL) & $5.10 \mathrm{c}$ & $5.23 \mathrm{bc}$ & 5.17 & $5.61 \mathrm{~b}$ & $5.60 \mathrm{c}$ & 5.61 \\
$\mathrm{~T}_{7}$ (Farmers' preserved PL) & $4.14 \mathrm{~d}$ & $4.68 \mathrm{~d}$ & 4.41 & $4.68 \mathrm{c}$ & $5.05 \mathrm{~d}$ & 4.87 \\
$\mathrm{~T}_{8}$ (50\% STB) & $3.92 \mathrm{~d}$ & $4.15 \mathrm{e}$ & 4.04 & $3.58 \mathrm{~d}$ & $4.55 \mathrm{e}$ & 4.07 \\
\hline
\end{tabular}

Note: All treatments received a blanket dose of $50 \%$ STB chemical fertilizer except $\mathrm{T}_{1}$ and $\mathrm{T}_{8}$. Means followed by same letter in a column do not differ significantly by $5 \%$ level of DMRT. 
Table 3. Nitrogen, phosphorous, potassium, and sulphur uptake by Boro rice as influenced by different aged poultry litter.

\begin{tabular}{|c|c|c|c|c|c|c|c|c|c|c|c|c|}
\hline \multirow{2}{*}{ Treat. } & \multicolumn{3}{|c|}{ N uptake (kg/ha) } & \multicolumn{3}{|c|}{ P uptake (kg/ha) } & \multicolumn{3}{|c|}{ K uptake (kg/ha) } & \multicolumn{3}{|c|}{ S uptake (kg/ha) } \\
\hline & 2005 & 2006 & Total & 2005 & 2006 & Total & 2005 & 2006 & Total & 2005 & 2006 & Total \\
\hline $\mathrm{T}_{1}$ & 38.81d & 35.93e & 76 & $8.13 \mathrm{bc}$ & $11.13 c$ & 19 & 4L77d & $41.41 \mathrm{e}$ & 83 & $7.15 c$ & 7.43e & 15 \\
\hline $\mathrm{T}_{2}$ & 91.59ab & 102.80a & 194 & 21.04ab & 31.89a & 53 & $87.62 b$ & $128.74 a$ & 216 & $17.28 \mathrm{a}$ & 21.63a & 39 \\
\hline $\mathrm{T}_{3}$ & 100.0la & 101.33a & 201 & $22.61 \mathrm{a}$ & 31.91a & 55 & $97.91 \mathrm{a}$ & $117.12 \mathrm{a}$ & 225 & $17.18 \mathrm{a}$ & $21.22 \mathrm{a}$ & 38 \\
\hline $\mathrm{T}_{4}$ & $84.04 b$ & $83.21 b$ & 167 & 19.43ab & $27.82 \mathrm{a}$ & 47 & $84.84 b$ & $101.74 b$ & 187 & $15.45 \mathrm{a}$ & $18.77 \mathrm{~b}$ & 34 \\
\hline $\mathrm{T}_{5}$ & $83.47 \mathrm{~b}$ & $76.20 \mathrm{bc}$ & 160 & 16.99abc & $25.70 \mathrm{a}$ & 43 & $80.55 b$ & $95.10 \mathrm{bc}$ & 176 & $15.16 a b$ & $16.88 \mathrm{bc}$ & 32 \\
\hline $\mathrm{T}_{6}$ & $80.04 b$ & 70.90cd & 151 & $16.88 \mathrm{abc}$ & $23.51 b$ & 40 & $82.09 b$ & $84.27 \mathrm{~cd}$ & 166 & $12.72 b$ & $15.48 \mathrm{c}$ & 28 \\
\hline $\mathrm{T}_{7}$ & $62.63 c$ & 63.34d & 126 & $13.20 \mathrm{bc}$ & $20.63 b$ & 34 & $65.25 c$ & $75.28 \mathrm{~cd}$ & 141 & $12.79 b$ & $13.67 \mathrm{~cd}$ & 26 \\
\hline $\mathrm{T}_{8}$ & $55.07 \mathrm{c}$ & $55.47 d$ & 111 & $13.48 \mathrm{bc}$ & $17.77 \mathrm{bc}$ & 31 & 55.59c & $66.70 \mathrm{~d}$ & 122 & $10.47 \mathrm{~b}$ & $12.37 d$ & 23 \\
\hline $\begin{array}{l}\text { LSD } \\
(0.05)\end{array}$ & 8.60 & 9.59 & - & 9.09 & 6.74 & - & 9.09 & 16.03 & - & 2.64 & 2.02 & - \\
\hline
\end{tabular}


Straw yield was significantly affected due to the application of PL and inorganic fertilizers (Table 2). Straw yield ranged from 2.98 to $6.51 \mathrm{t} / \mathrm{ha}$. The highest straw yield was obtained with 30 days aged PL, which was statistically identical to that obtained with fresh PL. The effects of these two treatments were superior to other treatments in producing straw yield. A lower trend was observed in the rest of the treatments for straw yield. Different combinations of chemical fertilizer with poultry manure $2 \mathrm{t}$ /ha gave the highest straw yield of rice as reported by Vanaja and Raju (2002).

\section{Nutrient uptake of Boro rice}

There were a significant difference in total nutrient uptake by rice due to the application of poultry litter and STB fertilizer (Table 3). The highest total N uptake by rice grain and straw (100 kg/ha) was observed in 30 days aged PL. This treatment produced the highest grain and straw yield; so it could bring about the highest total $\mathrm{N}$ uptake. This result is in conformity with the findings of Singh and Mandal (1997). A decreasing trend in $\mathrm{N}$ uptake was observed with increasing the storing time of PL. The highest total P uptake $(27.26 \mathrm{~kg} / \mathrm{ha})$ was obtained with 30 days aged PL followed by fresh PL and the lowest was observed in control. Increased P uptake by plant following addition of farmyard manure and green manure was reported by Maurya and Ghosh (1972). Similar trend was observed in case of $\mathrm{K}$ and $\mathrm{S}$ uptake by rice. The total uptake of these nutrients by the plant is the combined effect of nutrients contents in the plant as well as total biological yield. Combined effect of organic and inorganic source of nutrients increased the available NPK uptake. This was also reported by Ritamoni et al. (1999).

\section{Apparent nutrient balance}

In the present study, apparent nutrient balance was done as affected by different aged poultry litter and inorganic fertilizer management. In calculating apparent nutrient balance $30 \mathrm{~kg} \mathrm{~N}$ from irrigation water and $20 \mathrm{~kg} \mathrm{~N}$ from BNF were considered as $\mathrm{N}$ addition, with the $\mathrm{N}$ from urea and PL. Assuming that Boro rice crop requires $100 \mathrm{~cm}$ water/ha, thus the amount of $\mathrm{P}$ and $\mathrm{K}$ through irrigation water was $0.6 \mathrm{~kg}$ and $14 \mathrm{~kg} / \mathrm{ha}$, respectively.

Nitrogen replenishment through different aged poultry litter with chemical fertilizer was not enough to balance $\mathrm{N}$ removal by crops since much of the applied $\mathrm{N}$ was lost from the soil (Fig.1 $\mathrm{N}$ balance). The $\mathrm{P}$ and $\mathrm{S}$ balances were positive as expected. A decreasing trend was observed in case of $\mathrm{P}$ and $\mathrm{S}$ accumulation with increasing the decomposition time of PL (Fig. $1 \mathrm{P} \& \mathrm{~S}$ balance). Appreciable amounts of $\mathrm{P}$ were accumulated in fresh poultry treated plots. The lowest amount of $\mathrm{P}$ accumulation was in lone chemical fertilizer added plot and negative balance was in control plot. In case of $\mathrm{K}$, it was evident that $\mathrm{K}$ 
uptake by crops far exceeded the amount that was added as fertilizer (Fig.1 K balance). This will lead to $\mathrm{K}$ depletion in the long run. These results are in agreement with the findings of Haque et al. (2001) and Ali et al. (2009).

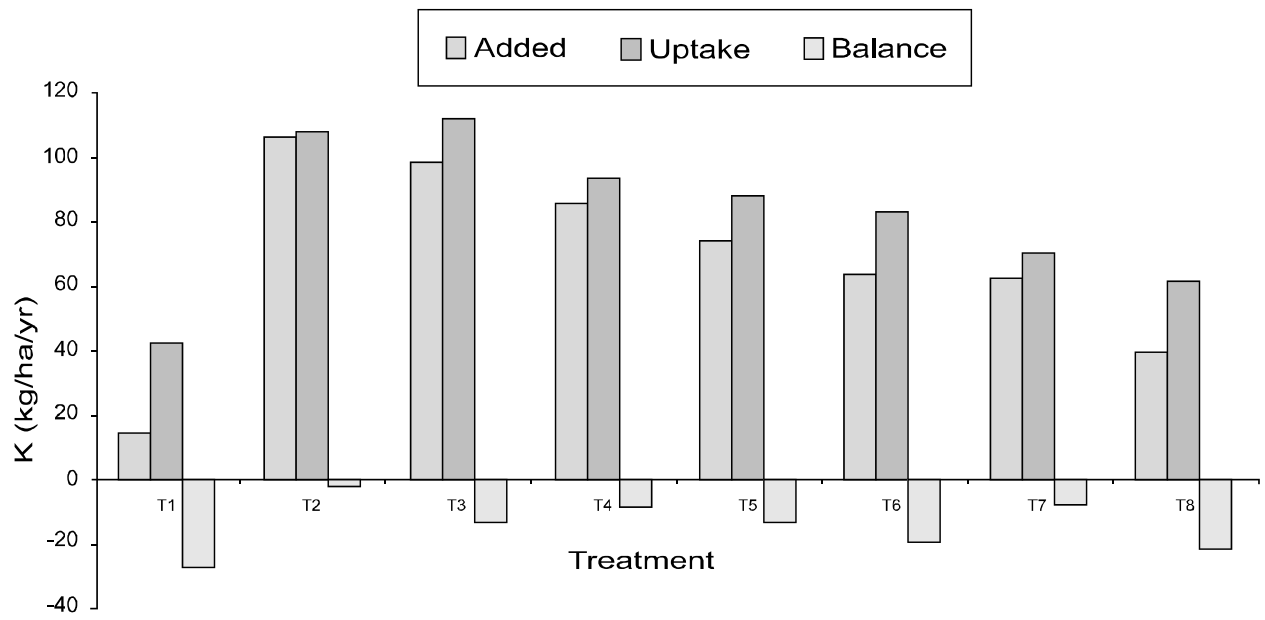

Fig. $\mathrm{N}$ balance

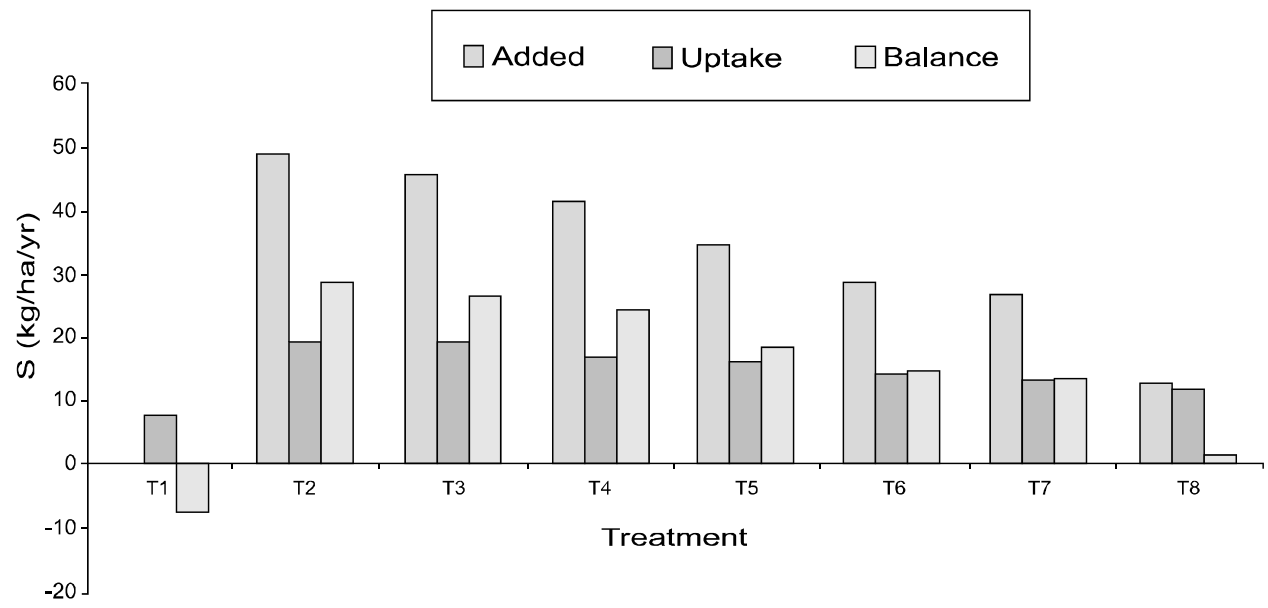

Fig. P balance 


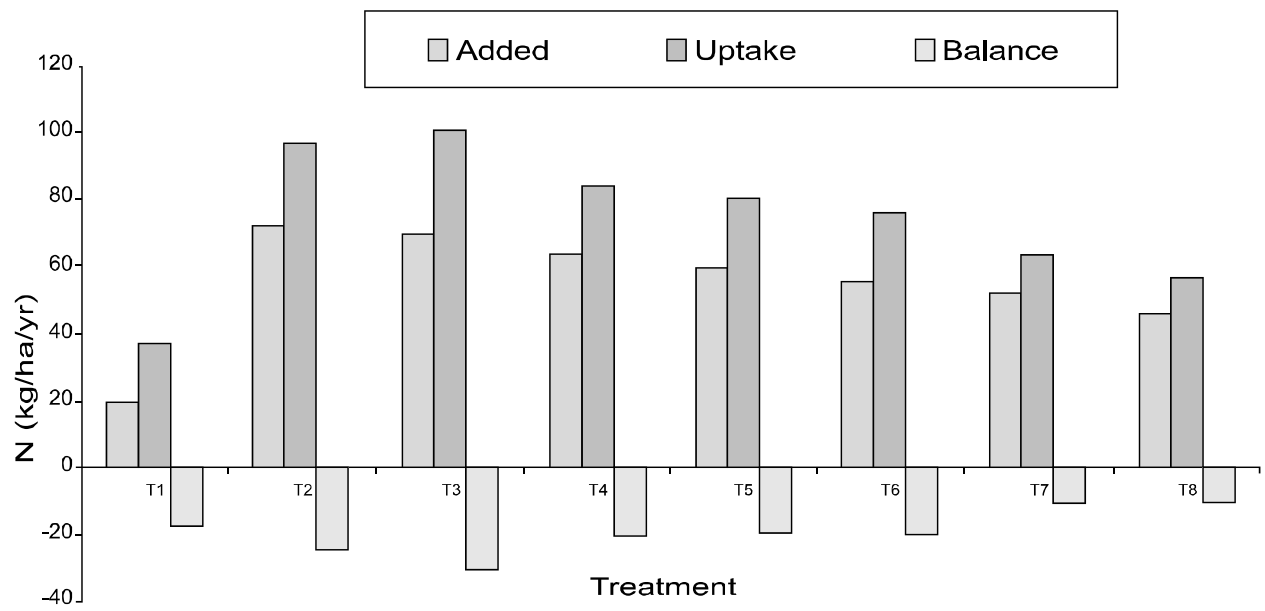

Fig. K balance

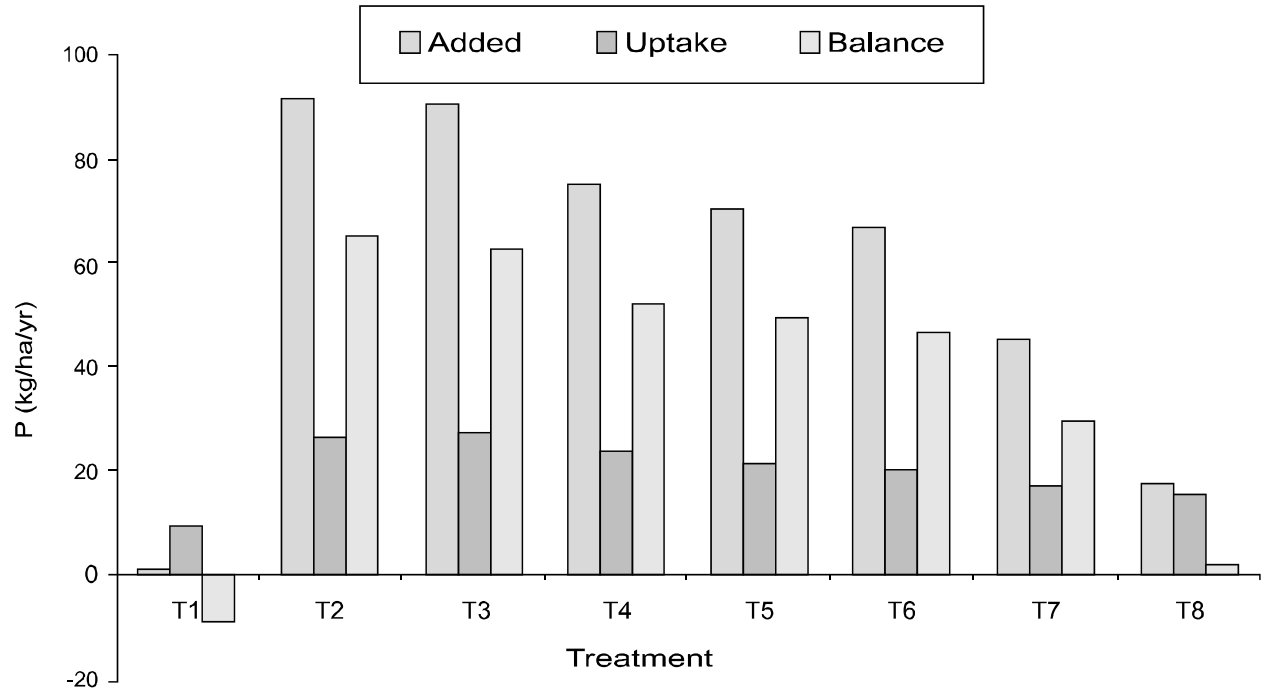

Fig. S balance

Fig. 1. Apparent nutrient balance in soil as affected by different aged poultry litter. Note $1: 30 \mathrm{~kg} \mathrm{~N}, 0.6 \mathrm{~kg} \mathrm{P}$ and $14 \mathrm{~kg} \mathrm{~K} / \mathrm{ha} /$ year added in soil through irrigation water. Note 2: Assumed $100 \mathrm{ha}^{-\mathrm{cm}}$ water requirement in Boro rice production.

Note 3: $40 \%$ of the applied $\mathrm{N}$ was assumed as effective.

For sustaining higher rice production, use of only chemical fertilizer would not be a judicial approach. Integrated nutrient management approach is necessary for higher rice yield as well as maintaining soil fertility. The two years results indicated that, thirty days aged PL with 50\% STB chemical fertilizer was superior and it may be recommended for better rice production. 


\section{References}

Ali, M. E., M.R Islam and M..Jahiruddin. 2009. Effect of integrated use of organic manures with chemical fertilizers in the rice-rice cropping pattern, and its impact on soil health. Bangladesh J. Agril. Res. 34(1): 8 1-90.

BRRI (Bangladesh Rice Research Institute). 1998-99. Annual Report for 1998-1999. Gazipur

Dick, R.P. and Christ.1995. Effect of long- term residue management and nitrogen fertilization on availability and profile distribution of nitrogen. Soil Sci. 159: 402408.

Eghball, B., J.F. Power, J.E. Gilley and J.W. Doran. 1997. Nutrient, carbon, and mass loss of beef cattle feedlot manure during composting. J. Environ. Qual. 26:189-193.

Egrinya Eneji, A., T. Honna and S. Yamamoto. 2001. Manuring effect on rice grain yield and extractable trace elements in soils. J. Plant Nutr. 24(7): 967-977

Hammond, C., B. Segars and C. Gould. 1997. Land Application of Livestock and Poultry Manure. www. bae. uga. edu.

Haque, M.Q., M.H. Rahman, F. Islam, J. Rijpma, and M.M. Kadir. 2001. Integrated nutrient management in relation to soil fertility and yield sustainability under wheatmung-T. Aman cropping pattern. Online J Biol. Sci. 1(8): 731-734.

Karim, Z., M.M.U. Miah and S. Razia. 1994. Fertilizer in the national economy and sustainable environment. Asia Paci. J. Environ. Dev. 2: 48-67.

Maurya, P.R. and A.B. Ghosh. 1972. Effect of long-term manuring and rotational cropping on fertility status of alluvial calcareous soil. J. Indian Soc. Soil Sci. 20: 3143.

Miah, M.A.M., M. Ishaque and P. K. Saha. 2006. Integrated nutrient management for improving soil health and rice production. Twenty first BRRI- DAE Joint Workshop on Bridging the Rice Yield Gap for Food Security. BRRI, Gazipur, Bangladesh, 19-2 1 September 2006. Paper 11, 1-15.

Rijpma, J. and M. Jahiruddin. 2004. Final report on National Strategy and Plan for Use of Soil Nutrient Balance in Bangladesh.

Ritamoni, B., T. Haridev, N.C. Talukder, R. Baruah and H. Talukder. 1999. Soil chemical properties as influenced by the application of fertilizer and farm yard manure. Int. J. Tropic.Agric.17 (1-4): 153-158.

Saha, P. K., A.T.M. S. Hossain, U.A. Naher and M.A. Saleque. 2004. Nutrient composition of some manure and crop residues. Bangladesh J. Agril. Res. 29(1): 165-168.

Singh, Y.V. and B.K. Mandal. 1997. Nutrition of rice through azolla, organic materials and urea. Indian J. Agron. 42: 626-63 3.

Vanaja, M. and A.S. Raju. 2002. Integrated nutrient management performance in rice crop. Abbakas Agric. Res. 23(91): 177-182. 